\title{
Determination of Pesticide Residues in curry leaf in local markets of Hyderabad, India
}

\author{
Swarupa Rani, S Shashi Vemuri, V.Venkateswara Reddy* \\ AINP on Pesticide Residues, PJTSAU, Hyderabad,Telangana state, India \\ *Jawaharlal Nehru Technological University,Hyderabad, India
}

\begin{abstract}
Studies were conducted for determining the residues of commonly used pesticides in curry leaf samples collected periodically from different markets of Hyderabad, India during 2013 - 2014. A total of 120 samples were collected from five selected markets of Hyderabad every month and analysed using QuEChERS method on LCMS/MS. The most commonly detected pesticide residues were of Profenophos (22.5\%), Ethion (20\%), Cyfluthrin (16.67\%), Bifenthrin (8.33\%), Chlorpyriphos (7.5\%), Dimethoate(7.5\%), Triazophos (5.83\%), Phorate (4.17\%), Methyl parathion (3.33\%) , cypermethrin (2.5\%), Fenpropathrin (2.5\%), Monocrotophos (2.5\%), Acetamaprid(1.67\%), Methamidophos(1.67\%). Acephate, Allethrin, alpha cypermethrin ,Fipronil, Carbendazim, Deltamethrin, Malathion, Quinalphos all (0.83\%) indicating that, curry leaf samples contained detectable level of the pesticides residues for which Maximum Residue Limits (MRL) are not fixed. As there are no MRLs for curry leaves, it should be considered as most important to fix MRLs to ensure food safety and consumer health and to create awareness among the farmers about the application dose, method of application and Pre Harvest Intervals. The mismanagement or non-availability of proper information about the pesticide application can lead to contamination of pesticide residues in curry leaf. The findings of this study provided important data about contamination of pesticide residues in curry leaf sold in the local markets of Hyderabad and hence, it is essential to conduct monitoring studies in other curry leaf growing agro climatic regions, which may serve as basis for future policy about the standards and quality control of pesticides.
\end{abstract}

Keywords-Curry leaf, QuEChERS method, Chlorpyriphos, Cypermethrin, Monocrotophos and LCMS/MS.

\section{INTRODUCTION}

Murraya koenigii L. (curry leaf) belonging to family Rutaceae is a leafy spice characterizing authentic AsianIndian cuisine and it is used in small quantities for its distinct aroma as well as for preservation purposes. Curry leaf oil an volatile oil, produced from the plant has uses in the soap industry. (Salikutty Joseph and Peter, 2008). Recent studies have shown that carbazole alkaloids have several biological activities such as anti carcinogenic effects in dimethyl hydrazine (DMH) treated rats (Khanum et al., 2000), anti platelet activity and vaso relaxing effects (Wu et al., 1998). Chevalier (1996) also reported that curry leaf has medicinal value as traditionally used in Eastern Asia. Interest in greater use of curry leaf has been stimulated since its high antioxidant potency was reported and this antioxidant activity is attributed due to maha nimbine, murrayanol and mahanine from $M$. koenigii (Tachibana et al., 2003; Ningappa et al.,2008). Chowdhury et al. (2001) reported that these alkaloids have antimicrobial activity against gram positive and negative bacteria, and fungi. Lee et al. (2002) noted that enrichment of phenolic compounds within the plant extract is correlated with their enhanced antioxidant activity, It is reported to have antioxidant, anti-diabetic, anti carcinogenic,anti dysenteric stimulant, hypo glycaemic and anti microbial activities (Khanum et al , 2000). Biologically active carbazole alkaloids are reported to have anti microbial properties (Ramsewak et al ,1999). Curry leaves have been reported to contain tocopherol, b-carotene, lutein and alkaloids (Khanum et al., 2000). But it is observed that curry leaves have received red alert message from the European Union, who are the major importers, where the pesticide residue limits were found much beyond the permissible levels. This created a panic among the mass as curry leaves constitute a major spice exported from India. Uncontrolled use of pesticides and non-adoption of safe waiting periods has led to pesticide accumulation in curry leaf crop. The residues being persistent in nature infiltrate crops, contaminate water, pollute complete food chain and enter our body through diet. Pesticide exposure may produce biochemical alterations in the body long before adverse clinical health effects are manifested (Khan et al., 2008). 
II.

\section{MATERIALS AND METHODS}

Market study

For the evaluation of pesticide residues, a total of 120 curry leaf samples were collected from five local markets of Hyderabad, India at monthly intervals for a period of two years from January 2013 - December 2014. Each sample was processed and analyzed for determination of pesticides. Samples were analyzed within $24 \mathrm{hrs}$.

Sample extraction procedure

curry leaf samples were analyzed for pesticide residues following the AOAC official method 2007.01 (QuEChERS) after validation of the method in the laboratory. The samples were collected randomly from 5 locations of the market in polythene bags. Each sample was homogenized separately with robot coupe blixer and homogenized $15 \pm 0.1 \mathrm{~g}$ sample was taken in $50 \mathrm{ml}$ centrifuge tube and $30 \pm 0.1 \mathrm{ml}$ acetonitrile was added to sample tube. The sample was homogenized at 14000-15000 rpm for 2-3 min using Heidolph silent crusher. $3 \pm 0.1 \mathrm{~g}$ sodium chloride was added to sample, mixed thoroughly by shaking gently followed by centrifugation for $3 \mathrm{~min}$ at 2500-3000 rpm to separate the organic layer. The top organic layer of about $16 \mathrm{ml}$ was taken into the $50 \mathrm{ml}$ centrifuge tube and added with $9 \pm 0.1 \mathrm{~g}$ anhydrous sodium sulphate to remove the moisture content. $8 \mathrm{ml}$ of extract was taken in to $15 \mathrm{ml}$ tube, containing $0.4 \pm 0.01 \mathrm{~g}$ PSA sorbent (for dispersive solid phase d-SPE cleanup),1.2 $\pm 0.01 \mathrm{~g}$ anhydrous magnesium sulphate and $0.05 \mathrm{~g}$ of $\mathrm{GCB}$ (Graphatised Carbon Black).The sample tube was vortexed for $30 \mathrm{sec}$ then followed by centrifugation for $5 \mathrm{~min}$ at 2500-3000rpm. The extract of about $1 \mathrm{ml}$ (0.5 g sample) was taken for analysis on LCMS/MS under standard operational conditions.( Table1).

Certified Reference Materials (CRM) of different pesticides having purity ranging from 95.10to 99.99 per cent were stored in a freezer at low temperature, with light and moisture excluded. Solvents used in the study were all glass distilled before use. Sodium sulphate, sodium chloride and magnesium sulphate were activated in hot air oven at $450{ }^{\circ} \mathrm{C}$ for $5 \mathrm{~h}$. A weighed amount of analytical grade material of each pesticide was dissolved in a minimum quantity of distilled acetone and diluted with methanol to obtain a stock solution of $1000 \mathrm{mg} \mathrm{kg-1}$ The intermediate standards and working standards of $0.5,0.25$, $0.1,0.05,0.025$ and $0.01 \mathrm{mg} \mathrm{kg}-1$ were prepared by suitably diluting the stock solution in methanol and used as standard check in analysis, linearity and recovery studies (Table-2).

Table.1: LC MS/MS Operating Parameters

\begin{tabular}{|c|c|}
\hline LC-MS/MS & SHIMADZU LCMS/MS - 8040. \\
\hline Detector & Mass Spectrophotometer \\
\hline Column & $\begin{array}{l}\text { Kinetex, } 2.6 \mu, \text { C18 Column, } 100 x \\
\text { 3.0. }\end{array}$ \\
\hline $\begin{array}{l}\text { Column oven } \\
\text { temperature }\end{array}$ & $40^{\circ} \mathrm{C}$ \\
\hline Nebulizing gas & Nitrogen \\
\hline $\begin{array}{l}\text { Nebulizing gas } \\
\text { flow }\end{array}$ & 2.0 litres/min \\
\hline Pump mode/ flow & Gradient / $0.4 \mathrm{ml} / \mathrm{min}$ \\
\hline Solvents & $\begin{array}{l}\text { A:Ammonium } \\
\text { FormateInWater(10Mm) } \\
\text { B: Ammonium Formate In } \\
\text { Methanol(10Mm) }\end{array}$ \\
\hline LC programme & $\begin{array}{lll}\text { Time } & \text { solvent } & \text { Conc } \\
0.01 & \text { B Conc } & 35 \% \\
2.00 & \text { B Conc } & 35 \% \\
7.00 & \text { B Conc } & 60 \% \\
9.00 & \text { B Conc } & 60 \% \\
14.00 & \text { B Conc } & 95 \% \\
17.00 & \text { B Conc } & 85 \% \\
19.00 & \text { B Conc } & 70 \% \\
21.00 & \text { B Conc } & 35 \% \\
24.00 & \text { B Conc } & 35 \%\end{array}$ \\
\hline $\begin{array}{l}\text { Total Time } \\
\text { Programme }\end{array}$ & $24 \mathrm{~min}$ \\
\hline
\end{tabular}

III. METHOD VALIDATION

The analytical method for estimation of residues of pesticides in curry leaves has been validated by conducting recovery studies using control samples. $15 \mathrm{~g}$ of sample was taken in $50 \mathrm{ml}$ centrifuge tubes in three replicates, each were spiked with pesticide mixture at the required fortification levels ie.LOQ, 5x LOQ and 10x LOQ, adding an appropriate volume of working standard. This mixture was then shaken to attain a proper homogeneity of pesticides in the samples. The tubes containing fortified samples were left open for a while, just to allow the evaporation of excess solvent. Sample extraction procedure was followed as given above. 
Levels of pesticides present in commodity was estimated using the formula: $=$ ( Peak area of sample $\times$ Volume of sample injected $\mathrm{x}$ Concentration of standard injected $\times$ Dilution Factor) / Peak area of standard $\mathrm{x}$ Volume of standard injected

Table.2: Average recoveries and R.S.Ds \% of different insecticides from curry leaf samples fortified at 10, 50 and 100ppb Levels.

\begin{tabular}{|c|c|c|c|c|c|c|c|c|c|}
\hline S.no & Pesticide & RT & $\begin{array}{c}\text { "Mean } \\
\text { recovery\% } \\
\text { (Spiking } \\
\text { Level } \\
\mathbf{0 . 0 1} \\
\text { mg/Kg)" }\end{array}$ & $\begin{array}{l}\text { RSD\% } \\
(n=3)\end{array}$ & $\begin{array}{c}\text { "Mean } \\
\text { recovery\% } \\
\text { (Spiking } \\
\text { Level } \\
\text { 0.050 } \\
\text { mg/Kg)" }\end{array}$ & $\begin{array}{l}\text { RSD\% } \\
(n=3)\end{array}$ & $\begin{array}{c}\text { "Mean } \\
\text { recovery \% } \\
\text { (Spiking } \\
\text { Level } \\
\text { 0.100 } \\
\text { mg/Kg)" }\end{array}$ & $\begin{array}{l}\text { RSD\% } \\
(n=3)\end{array}$ & $\mathbf{R}^{2}$ \\
\hline 1 & Abamectin & 18.1 & 112 & 3.6 & 97 & 15.1 & 111 & 1.9 & 0.9941 \\
\hline 2 & Acephate & 1.3 & 82 & 1.2 & 97 & 15.0 & 100 & 1.4 & 0.997 \\
\hline 3 & Acetamprid & 2.9 & 101 & 1.3 & 90 & 11.3 & 101 & 1.8 & 0.999 \\
\hline 4 & Alachlor & 14.0 & 96 & 0.8 & 91 & 2.3 & 112 & 2.2 & 0.997 \\
\hline 5 & Allethrin & 16.8 & 96 & 2.3 & 91 & 11.6 & 105 & 2.3 & 0.992 \\
\hline 6 & Anilophos & 15.1 & 89 & 17.4 & 101 & 14.1 & 98 & 1.4 & 0.992 \\
\hline 7 & Atrazine & 10.0 & 96 & 1.9 & 91 & 3.6 & 103 & 2.1 & 0.998 \\
\hline 8 & $\begin{array}{l}\text { Azinophos } \\
\text { ethyl }\end{array}$ & 13.9 & 89 & 0.7 & 92 & 5.4 & 114 & 1.9 & 0.997 \\
\hline 9 & Bifenthrin & 18.8 & 119 & 1.4 & 88 & 10.6 & 97 & 1.4 & 0.990 \\
\hline 10 & Carbaryl & 8.7 & 99 & 2.8 & 91 & 2.7 & 99 & 2.2 & 0.999 \\
\hline 11 & Carbendazim & 4.0 & 96 & 2.0 & 90 & 9.2 & 91 & 2.1 & 0.998 \\
\hline 12 & Carbofuran & 7.9 & 112 & 2.0 & 94 & 3.1 & 107 & 2.4 & 0.998 \\
\hline 13 & Chlorfenviphos & 15.3 & 91 & 0.9 & 99 & 15.8 & 92 & 0.5 & 0.997 \\
\hline 14 & Chlorpyriphos & 17.0 & 112 & 5.3 & 94 & 17.9 & 87 & 1.4 & 0.978 \\
\hline 15 & Cypermethrin & 17.7 & 98 & 2.9 & 99 & 16.7 & 104 & 2.6 & 0.966 \\
\hline 16 & $\begin{array}{l}\text { Demeton-s- } \\
\text { methylsulfone }\end{array}$ & 1.6 & 92 & 12.6 & 100 & 7.0 & 105 & 4.6 & 0.997 \\
\hline 17 & Diazonin & 15.3 & 93 & 0.6 & 96 & 19.3 & 113 & 3.0 & 0.996 \\
\hline 18 & Dimethoate & 2.9 & 104 & 0.5 & 88 & 3.6 & 100 & 1.7 & 0.998 \\
\hline 19 & Ethion & 16.9 & 111 & 0.6 & 92 & 17.4 & 103 & 1.1 & 0.993 \\
\hline 20 & Fenamidone & 12.2 & 97 & 1.2 & 96 & 15.0 & 103 & 1.9 & 0.998 \\
\hline 21 & Fenpropathrin & 17.0 & 101 & 6.2 & 97 & 13.1 & 102 & 2.2 & 0.984 \\
\hline 22 & Hexaconazole & 15.3 & 95 & 2.2 & 99 & 1.8 & 99 & 1.4 & 0.995 \\
\hline 23 & Imidacloprid & 2.2 & 116 & 3.9 & 97 & 5.7 & 105 & 1.9 & 0.996 \\
\hline 24 & Indoxycarb & 16.1 & 88 & 7.5 & 88 & 3.1 & 94 & 1.5 & 0.986 \\
\hline 25 & L-cyhalothrin & 17.6 & 105 & 6.2 & 103 & 18.8 & 108 & 9.7 & 0.975 \\
\hline 26 & Malathion & 13.0 & 114 & 3.5 & 98 & 18.5 & 99 & 2.3 & 0.999 \\
\hline 27 & Malaxon & 8.5 & 103 & 0.6 & 91 & 7.5 & 107 & 1.3 & 0.998 \\
\hline 28 & Metalaxyl & 10.4 & 104 & 0.7 & 104 & 10.8 & 106 & 1.7 & 0.998 \\
\hline 29 & Methamidophos & 1.3 & 102 & 1.3 & 99 & 17.2 & 99 & 1.6 & 0.998 \\
\hline 30 & Methomyl & 1.7 & 81 & 12.9 & 101 & 1.5 & 85 & 4.1 & 0.994 \\
\hline 31 & Myclobutanil & 13.2 & 90 & 16.9 & 93 & 12.4 & 96 & 4.4 & 0.985 \\
\hline 32 & Nitenpyram & 14.0 & 93 & 1.4 & 89 & 8.3 & 103 & 1.8 & 0.996 \\
\hline 33 & Penconazole & 14.9 & 107 & 0.6 & 92 & 12.9 & 91 & 1.7 & 0.992 \\
\hline 34 & Pendimethalin & 17.1 & 88 & 3.8 & 102 & 13.8 & 94 & 1.5 & 0.997 \\
\hline
\end{tabular}




\begin{tabular}{|l|l|c|c|c|c|c|c|c|c|}
\hline 35 & Phorate & 15.5 & 99 & 2.6 & 95 & 16.8 & 110 & 2.1 & 0.993 \\
\hline 36 & Phosalone & 15.1 & 89 & 3.5 & 88 & 6.1 & 117 & 2.3 & 0.987 \\
\hline 37 & Phosphomidan & 7.0 & 90 & 1.2 & 89 & 2.6 & 102 & 1.5 & 0.999 \\
\hline 38 & Profenophos & 16.4 & 109 & 1.7 & 99 & 15.9 & 106 & 1.7 & 0.994 \\
\hline 39 & Quinolphos & 14.8 & 91 & 0.8 & 94 & 16.2 & 102 & 1.1 & 0.996 \\
\hline 40 & Simazine & 7.8 & 97 & 7.5 & 97 & 16.1 & 98 & 2.0 & 0.998 \\
\hline 41 & Spinosad-a & 17.7 & 116 & 2.3 & 93 & 2.3 & 106 & 2.3 & 0.994 \\
\hline 42 & Spinosad-d & 18.1 & 98 & 1.2 & 90 & 8.5 & 99 & 1.9 & 0.993 \\
\hline 43 & Spiromesifen & 17.3 & 113 & 1.3 & 87 & 7.5 & 95 & 1.6 & 0.991 \\
\hline 44 & Spirotetramate & 14.0 & 91 & 16.9 & 97 & 9.3 & 103 & 1.7 & 0.986 \\
\hline 45 & Tebuconazole & 15.0 & 88 & 0.5 & 90 & 16.2 & 94 & 1.6 & 0.991 \\
\hline 46 & Thiacloprid & 3.9 & 112 & 3.1 & 102 & 12.9 & 96 & 1.8 & 0.998 \\
\hline 47 & Thiamethoxam & 1.7 & 97 & 2.0 & 90 & 2.7 & 103 & 1.5 & 0.993 \\
\hline 48 & Tricyclozole & 4.8 & 83 & 0.7 & 93 & 8.1 & 96 & 1.8 & 0.997 \\
\hline 49 & Trifloxy & 16.1 & 97 & 1.6 & 91 & 9.4 & 90 & 2.7 & 0.997 \\
\hline
\end{tabular}

\section{RESULTS AND DISCUSSIONS}

A multi residue method was used to monitor 49 pesticide residues by LC MS-MS. The targeted 22 pesticides were detected ( Table -3) and quantified based on calibration standard at $0.1 \mathrm{mg} \mathrm{kg}-1$ and of the 120 curry leaf samples analysed 71 samples were detected with more than one pesticide . 27 of them were contaminated with Profenophos, 24 with ethion, 20 with cyfluthrin, 10 with bifenthrin, 9 with chlorpyrifos, 7 with triazophos, 5 with phorate, 4 with methyl parathion, 3 with monocrotophos, 2 samples with methamidophos and one each with quinalphos, malathion, acephate, allethrin, alphacypermethrin, carbendazim, deltamethrin and fipronil residues. Residue levels of Profenophos were high (25.69 mg kg-1) followed by B- Cyfluthrin and monocrotophos (12.65mg kg-1 and $12.23 \mathrm{mg} \mathrm{kg-1),} \mathrm{cypermethrin}$ (10.81 mg kg-1), dimethoate (4.90 mg kg-1), ethion (4.79 mg kg-1), bifenthrin (2.87 mg kg-1), chlorpyrifos(1.86 mg kg-1), while allethrin was the least (0.046 mg kg-1)( Fig-1). Most of the pesticides detected were Organo Phosphates and Synthetic Pyrethroids This exhibits the shift from Organochlorines to OPs and SP insecticides and the restricted use of $\mathrm{OC}$ insecticides. The results obtained in the present study are in agreement with those of Fytianos et al.1985, and Gupta et al,1998. The pesticides detected during the three seasons ( Rainy, winter and summer seasons and year wise in 2013 and 2014( Figs 2 to 4 and tables 4 -5) shows different pesticides in different seasons at different levels. During rainy season the residues of cyfluthrin $2.16 \mathrm{mg} \mathrm{kg}-1$ and bifenthrin at $1.15 \mathrm{mg} \mathrm{kg} \mathrm{-1}$ and the lowest of $0.05 \mathrm{mg} \mathrm{kg}-1$ of allethrin were detected. However in winter season Methmidophos residues were the highest ( $12.33 \mathrm{mg} \mathrm{kg} \mathrm{-1)} \mathrm{followed} \mathrm{by} \mathrm{cyfluthrin} \mathrm{(} 4.03 \mathrm{mg}$ $\mathrm{kg} \mathrm{-1)}$ and bifenthrin ( $0.93 \mathrm{mg} \mathrm{kg}-1$ ).In summer season among the pesticide residues detected alphamethrin was the highest ( $6.29 \mathrm{mg} \mathrm{kg} \mathrm{-1)} \mathrm{followed} \mathrm{by} \mathrm{cypermethrin} \mathrm{(} 5.64$ $\mathrm{mg} \mathrm{kg} \mathrm{-1)} \mathrm{where} \mathrm{as} \mathrm{bifenthrin} \mathrm{residues} \mathrm{detected} \mathrm{were} 1.03$ $\mathrm{mg} \mathrm{kg}-1$. Lowest of $0.09 \mathrm{mg} \mathrm{kg}-1$ of phorate was detected.. Cyfluthrin, bifenthrin and ethion residues were the commonly detected pesticides in all 3 seasons. Intensive cultivation technologies produce high infestation of crops by some pests and diseases, trigger off major losses of quality crops and initiate the use of more pesticides. The increase in frequency and magnitude of residues in the curry leaf samples could be attributed to indiscriminate and over use of pesticides by farmers despite efforts by various concerned agencies. It has been found that the farmers are neither following recommended waiting periods nor abide by good agricultural practices (GAP). (Bhanti et al., 2004). Therefore an effective way of educating the farmers via training and electronic media is advised particularly in view of the export potential of the crop. A periodical monitoring studies of pesticide residues may be extended to different agro climatic regions to know actual status of contamination and to strengthen the confidence of consumer in quality of food as well as food quality control authorities for future policies.

Table.3: Retention time, MRL values and pesticide residues ( $\mathrm{mg} / \mathrm{kg}$ ) detected in curry leaf samples during 2013 to 2014. 


\begin{tabular}{|c|c|c|c|c|c|c|c|}
\hline \multirow{2}{*}{ S.No } & \multirow{2}{*}{ Pesticide } & \multirow{2}{*}{$\begin{array}{l}\text { RT } \\
(\min )\end{array}$} & \multirow{2}{*}{$\begin{array}{l}\text { No of samples } \\
\text { contaminated } \\
\text { with each } \\
\text { pesticide }(n=120)\end{array}$} & \multirow{2}{*}{$\begin{array}{c}\% \\
\text { of samples } \\
\text { contaminated }\end{array}$} & \multicolumn{3}{|c|}{ Residue range $(\mathrm{mg} / \mathrm{kg})$} \\
\hline & & & & & Min & $\operatorname{Max}$ & Mean \\
\hline 1. & Acephate & 1.3 & 1 & 0.83 & 0.285 & 0.286 & 0.286 \\
\hline 2. & Acetamaprid & 2.9 & 2 & 1.67 & 0.071 & 0.095 & 0.083 \\
\hline 3. & Allethrin & 16.8 & 1 & 0.83 & 0.046 & 0.046 & 0.046 \\
\hline 4. & cypermethrin & 17.48 & 1 & 0.83 & 0.050 & 0.050 & 0.050 \\
\hline 5. & Bifenithrin & 18.8 & 10 & 8.33 & 0.131 & 2.874 & 1.503 \\
\hline 6. & Carbendazim & 4 & 1 & 0.83 & 0.080 & 0.080 & 0.080 \\
\hline 7. & Chlorpyrifos & 17 & 9 & 7.50 & 0.184 & 1.860 & 1.022 \\
\hline 8. & Cyfluthrin & & 20 & 16.67 & 1.065 & 12.654 & 6.860 \\
\hline 9. & Cypermethrin & 17.7 & 3 & 2.50 & 0.345 & 10.810 & 5.578 \\
\hline 10. & Deltamethrin & 17.55 & 1 & 0.83 & 0.369 & 0.369 & 0.369 \\
\hline 11. & Dimethoate & 2.9 & 9 & 7.50 & 0.075 & 4.902 & 2.489 \\
\hline 12. & Ethion & 16.9 & 24 & 20.00 & 0.070 & 4.790 & 2.430 \\
\hline 13. & Fenpropathrin & 17 & 3 & 2.50 & 0.262 & 1.095 & 0.679 \\
\hline 14. & Fipronil & & 1 & 0.83 & 0.091 & 0.091 & 0.091 \\
\hline 15. & Malathion & 13 & 1 & 0.83 & 1.739 & 1.739 & 1.739 \\
\hline 16. & Methamidophos & 1.3 & 2 & 1.67 & 0.120 & 0.256 & 0.188 \\
\hline 17. & Methyl parathion & & 4 & 3.33 & 0.050 & 0.187 & 0.119 \\
\hline 18. & Monocrotophos & 1.67 & 3 & 2.50 & 0.478 & 12.231 & 6.355 \\
\hline 19. & Phorate & 15.5 & 5 & 4.17 & 0.055 & 0.548 & 0.302 \\
\hline 20. & Profenofos & 16.4 & 27 & 22.50 & 0.063 & 25.690 & 12.877 \\
\hline 21. & Quinalphos & 14.8 & 1 & 0.83 & 1.017 & 1.017 & 1.017 \\
\hline 22. & Triazophos & & 7 & 5.83 & 4.330 & 0.110 & 2.220 \\
\hline
\end{tabular}

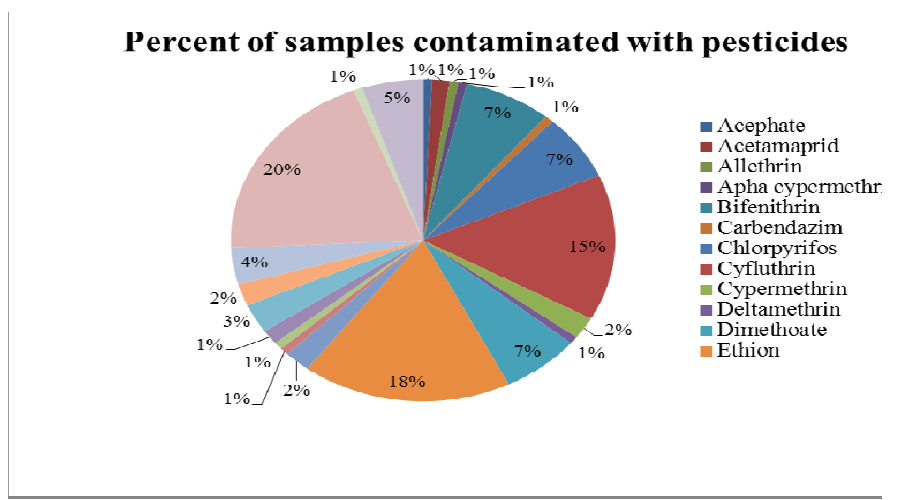

Fig.1: Percent Samples contaminated with pesticides

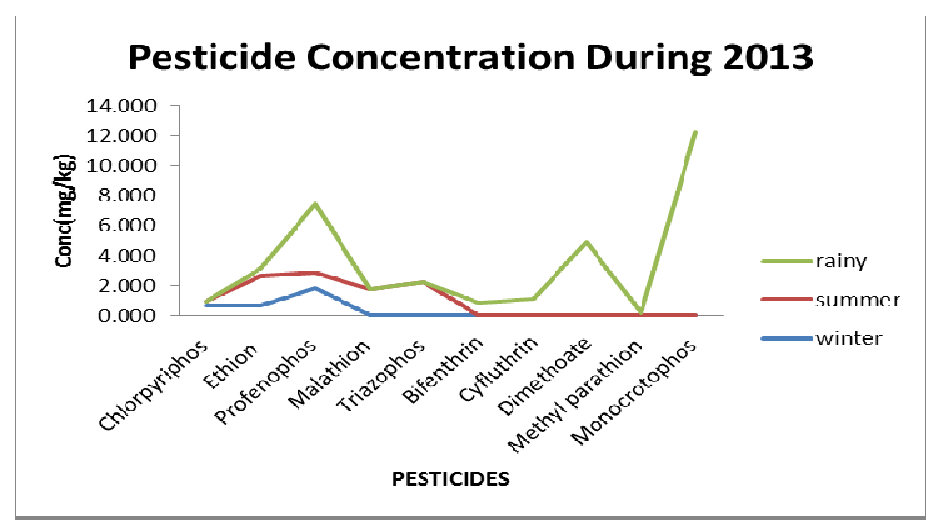

Fig.2: Pesticide Concentration during 2013 


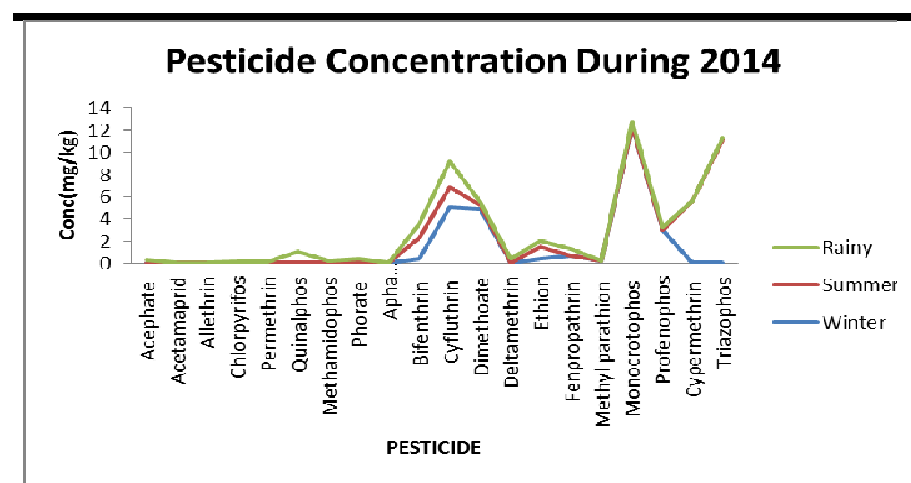

Fig.3: Pesticide concentration during 2014
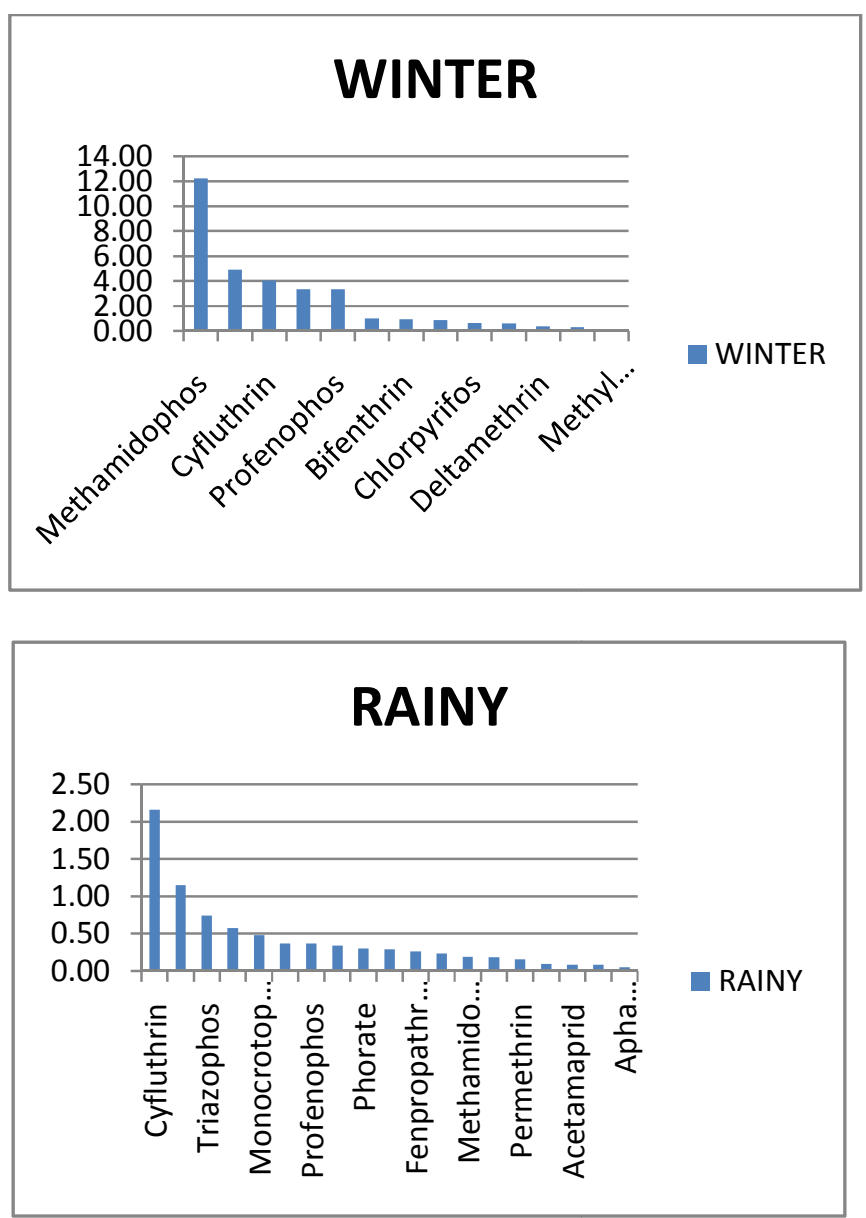

\section{SUMMER}

8.00

6.00

4.00

2.00

0.00

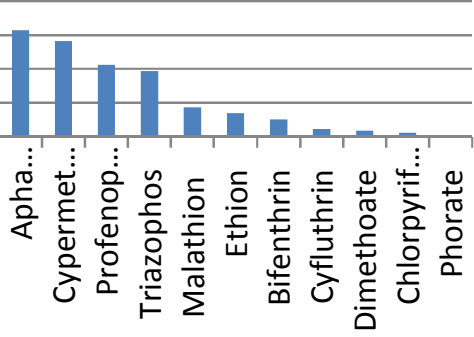

SUMMER
Fig.4: Pesticides detected in different seasons on curry leaf

\begin{tabular}{|l|l|l|l|}
\hline \multicolumn{4}{|c|}{ Table.4: PESTICIDE CONCENTRATION DURING } \\
\hline Pesticide & Winter & Summer & Rainy \\
\hline Chlorpyriphos & 0.664 & 0.240 & - \\
\hline Ethion & 0.685 & 1.930 & 0.493 \\
\hline Profenophos & 1.791 & 1.030 & 4.617 \\
\hline Malathion & - & 1.739 & - \\
\hline Triazophos & - & 2.237 & - \\
\hline Bifenthrin & - & - & 0.850 \\
\hline Cyfluthrin & - & - & 1.065 \\
\hline Dimethoate & - & - & 4.902 \\
\hline Methyl parathion & - & - & 0.187 \\
\hline Monocrotophos & - & - & 12.231 \\
\hline
\end{tabular}

Table.5: Pesticide Concentration During 2014

\begin{tabular}{|l|l|l|l|}
\hline Pesticide & Winter & Summer & Rainy \\
\hline Acephate & - & - & 0.286 \\
\hline Acetamaprid & - & - & 0.083 \\
\hline Allethrin & - & - & 0.046 \\
\hline Chlorpyrifos & - & - & 0.121 \\
\hline Permethrin & - & - & 0.156 \\
\hline Quinalphos & - & - & 1.017 \\
\hline Methamidophos & - & - & 0.188 \\
\hline Phorate & - & 0.091 & 0.305 \\
\hline Aphacypermethrin & - & 0.050 & - \\
\hline Bifenthrin & 0.381 & 1.930 & 1.187 \\
\hline Cyfluthrin & 5.053 & 1.804 & 2.325 \\
\hline Dimethoate & 4.902 & 0.362 & 0.233 \\
\hline Deltamethrin & - & - & 0.369 \\
\hline Ethion & 0.404 & 1.044 & 0.590 \\
\hline
\end{tabular}




\begin{tabular}{|l|l|l|l|}
\hline Fenpropathrin & 0.645 & - & 0.679 \\
\hline Methyl parathion & 0.187 & - & 0.052 \\
\hline Monocrotophos & 12.231 & - & 0.478 \\
\hline Profenophos & 2.971 & - & 0.293 \\
\hline Cypermethrin & - & 5.555 & - \\
\hline Triazophos & - & 11.124 & 0.139 \\
\hline
\end{tabular}

\section{REFERENCES}

[1] Bhanti, M., Shukla, G. and Taneja, A. (2004) Contamination levels of organochlorine pesticides and farmers' knowledge, perception, practices in rural India-A case study,Bull EnvironContam Toxicol, 73, 787-793.

[2] Chevallier, A. 1996. The encyclopedia of medicinal plants.Darling Kindersley, London, UK.

[3] Chowdhury, B.K., Jha, S., Bhattacharyya, P. and Mukherjee, J. 2001. Two new carbazole alkaloids from

Murraya koenigii. Indian Journal of Chemistry 40: 490-494.

[4] Khanum, Farhath, Sudarshana Krishna, K.R.,Viswanathan, K.R., and Santhanam, K.2000. Anticarcinogenic effects of curry leaves in dimethylhydrazine treated rats.Plant Food and Human Nutrition 55:347-355.

[5] Fytianos, K., Vasilikiotis, G., Weil, L, Kavlendis, E. and Laskaridis, N. (1985) Preliminary study of organochlorine compounds in milk products, human milk and vegetable. Bull Environ Contam Toxicol.34:504-508.

[6] Gupta, A., Singh, B., Parihar ,N.S. and Bhatnagar, A. (1998) Pesticide residues in the farm gate samples of bottle gourd, cauliflower, cabbage and fenugreek at Jaipur. Pesticide Res. J., 10 (1):86-90.

[7] Khan, A.D., M.M. Bhatti, F.A. Khan, S.T. Naqvi and A. Karam, Adverse effects of Pesticides Residues on Biochemical Markers in Pakistani Tobacco Farmers, Int. J. Clin. Exp. Med., 1, 2008, 274-282.

[8] Khanum, F., Anilakumar, K. R., Sudarshana Krishna, K. R., Viswanathan, K. R., \&Santhanam, K. (2000). Anticarcinogenic effects of curry leaves in dimethylhydrazine-treated rats. Plant Foods for Human Nutrition, 55, 347-355.

[9] Lee, J.C., Kim, H.R., Kim, J. and Jang, Y. S. 2002. Antioxidant activity of ethanol extract of the stem Of Opuntia ficus-indica var. saboten. Journal of Agriculture and Food Chemistry 50: 6490-6496.
[10] Ningappa, M.B., Dinesha, R., and Srinivas, L. 2008. Antioxidant and free radical scavenging activities of polyphenol-enriched curry leaf (Murraya koenigii L.) extracts. Food Chemistry 106: 720-728.

[11] Ramsewak, R. S., Nair, M. G., Strasburg, G. M., De Witt, D. L., \&Nitiss, J. L. (1999). Biologically active carbazole alkaloids from Murraya koenigii. Journal of Agricultural and Food Chemistry,47,444 - 447.

[12] Salikutty Joseph and K. V. Peter, Curry leaf ( Murrayakoenigii ), perennial, nutritious, leafy vegetable, Economic Botany 2008 , 39 (1): 68-73.

[13] Tachibana, Y., Kikuzaki, H., Lajis, N.H. and Nakatani, N. 2003. Comparison of antioxidative properties of carbazole alkaloids from Murrayakoenigii leaves. Journal of Agriculture and Food Chemistry 51: 6461-6467.

[14] Wu, T.S., Chan, Y.Y., Liou, M.J., Lin, F.W., Shi, L.S. and Chen, K. T. 1998. Platelet aggregation inhibitor from Murraya keonigii. Phytotherapy Research, 12: 380- 382 